\title{
Evaluation of the Brazilian Cosmetic Legislation and its impact on the industries during the $20^{\text {th }}$ century
}

\author{
Wanessa Almeida Ciancaglio Garbossa, Patrícia Maria Berardo Gonçalves Maia Campos*
}

Faculty of Pharmaceutical Sciences of Ribeirão Preto, University of São Paulo, Ribeirão Preto, Brazil

\begin{abstract}
Cosmetics have been used since the very first days of human life. This early and continuing consumption has resulted in the growth of the Cosmetic Industry (C.I.). The C.I. must continue to invest in the development of innovative products which are safe for the consumers. On the other hand, the Health Agency should issue laws regulating the development of products. Thus, the aim of this study was to evaluate the Brazilian Cosmetic Legislation before ANVISA and the challenges for the C.I. during the 20th century regarding the development of safe and effective cosmetics, and to show the importance of this legislation in the R\&D. A Bibliographic and Documentary Exploratory Research was conducted based on safety and efficacy data contained in scientific studies and legal documents. The study showed that the creation of ANVISA was necessary because no resolution had been published about the safety and efficacy of cosmetics for the C.I. before ANVISA. However, the challenges faced by the C.I. may have had a negative impact on the health of consumers. Finally, it was concluded that the actions before ANVISA were insufficient to the C.I.. Thus, the creation of ANVISA was essential to have a regulatory basis fot the C.I.
\end{abstract}

Uniterms: Brazil/Sanitary Agency/cosmetics production. Brazil/cosmetic legislation. Cosmetics/safety production. Cosmetic industry.

Os cosméticos são usados desde os primeiros dias de vida do ser humano. Consequentemente, esse consumo resulta no crescimento da Indústria Cosmética (I.C.). Com isso, a I.C. deve focar seus investimentos também no desenvolvimento de produtos inovadores, mas, acima de tudo, seguros para os consumidores. Por outro lado, a Agência Sanitária deve emitir leis que regulam o desenvolvimento desses produtos. Assim, o objetivo deste estudo foi avaliar a Legislação Cosmética Brasileira anterior à ANVISA e os desafios da I.C. no século XX no desenvolvimento de produtos cosméticos seguros e eficazes, bem como mostrar a importância dessa legislação na P\&D. Para tal, realizou-se uma Pesquisa Exploratória Bibliográfica e Documental com base em estudos científicos e documentos legais. Dessa forma, o estudo mostrou que a criação da ANVISA foi necessária porque nenhuma resolução tinha sido publicada sobre a segurança e eficácia de cosméticos antes da ANVISA. Com isso, os desafios enfrentados pela I.C. poderiam ter um impacto negativo sobre a saúde dos consumidores. Por fim, concluiu-se que as ações anteriores à ANVISA foram insuficientes para a I.C. Assim, a criação da ANVISA foi essencial para ter uma base regulatória para a I.C..

Unitermos: Brasil/Agência Sanitária/produção de cosméticos. Brasil/legislação de cosméticos. Cosméticos/produção/segurança. Indústria cosmética.

*Correspondence: P. M. B. G. Maia Campos. Faculdade de Ciências Farmacêuticas de Ribeirão Preto. Universidade de São Paulo. Av. do Café, s/n - 14040903 - Ribeirão Preto -Brasil. E-mail: pmcampos@usp.br 


\section{INTRODUCTION}

Considered essential products, hygiene products, perfumes and cosmetics, in this study referred to as "cosmetic products", have been present since the very first days of human life, mainly related to daily hygiene. On the other hand, cosmetic products also contribute to the maintenance or improvement of health because they protect against environmental damage such as solar radiation or low humidity, they correct imperfections of the skin and contributeto self-esteem.

This early and continuing consumption has resulted in the growth of the Cosmetic Industry. According to ABIHPEC,from 1996 to 2012 the Brazilian Cosmetic Industry has shown a growth of $10 \%$ per year compared to a $2.2 \%$ growth per year of the other industries (ABIHPEC, 2013).

This growth may be the result of several factors such as the increasing income of the D and E classes and the consumption of products with 'added value', the participation of women in the labor market, and productivity. In addition, the different technologies available to launch new products, the increased life expectancy, the search for rejuvenation, the awareness of the need for sun protection and the Brazilian exports have led to an increasing supply of products (ABIHPEC, 2013).

However, this subject should not be evaluated only from an economic perspective, but the development of safe and effective products should also be encouraged. Therefore, the Cosmetic Industry should continue to invest in the development of innovative products which are safe for the consumers. In addition, the Health Agency should issue laws for the development and marketing of products according to available standards and guidelines, following Good Manufacturing Practices, and regulating these products by completing Safety and Efficacy Studies.

The Brazilian Health Surveillance Agency (ANVISA) was created by law No 9782 of January 26, 1999 (Brasil, 1999). The creation of ANVISA aimed to centralize actions regarding sanitary regulation in order to determine how products and services can impact on people's health, including those of the Cosmetic Industry. However, to understand the creation of ANVISA and its importance for the cosmetic area, it was necessary to evaluate the legislation, focusing on publications related to the safety and efficacy of cosmetic products.

In addition to specific publications in this area, publications ofrelated areas were also evaluated, as well as non-regulatory publications that had a significant impact on the regulation of these products. Thus, the present literature and the documents from exploratory research have provided relevant information for the industrial and scientific community and have contributed to the consolidation of the importance of ANVISA for the continuous monitoring, assessment, guidance, regulation of research, development and innovation (RD\&I) and marketing of safe and effective cosmetic products.

\section{OBJECTIVE}

The aim of this study was to evaluate the Brazilian Cosmetic Legislation before the creation of ANVISA and the challenges for the Cosmetic Industry during the 20th century regarding the development of safe and effective cosmetic products, as well as to show the importance of knowledge of health legislation in the Research Development and Innovation (RD\&I) area.

\section{MATERIAL AND METHODS}

\section{Evaluation of the Brazilian Cosmetic Legislation beforethe creation of ANVISA}

\section{Exploratory Research}

The Brazilian Cosmetic Legislation was evaluated by Bibliographic and Documentary Exploratory Research (Raupp, Beuren, 2003; Sá-Silva, Almeida, Guindani, 2009) based on available safety and efficacy data. The Exploratory Research was chosen in order to obtain a broad view of the subject under study (Gil, 2008), i.e., the Cosmetic Legislation in Brazil before ANVISA. In addition, according to Raupp, Beuren (2003), this research is defined as an initial survey, in which the researchers observe any important information and seek to understand more about this subject.

The choice of this type of research involved investigations published in the area, such as research about hospital law (Feldstein, Melnick, 1984), the problems of legislation (Lorenzo, 1994), the impact of legislation on small businesses (Heriot, Lang, Thompson, 2010), as well as European and United States legislation about Phototoxicity Studies (Seto et al., 2012). Thus, we evaluated data contained in books, articles, theses (Bibliographic Exploratory Research) and decrees, laws, rules and resolutions (Documentary Exploratory Research).

\section{Data analysis}

The results were organized in a chronological comparison of regulatory milestones in the cosmetic area and related areas. 


\section{RESULTS AND DISCUSSION}

Figure 1 shows the main legislation and milestones of the cosmetic area in the $20^{\text {th }}$ century until the creation of ANVISA.

\begin{tabular}{|c|c|c|}
\hline 1997 & & Ordinance No. 348: Regulation of Good Manufacturing Practice \\
\hline 1995 & & Creation of CTAC \\
\hline 1995 & & Creation of $\mathrm{ABIHPEC}$ \\
\hline 1994 & & Ordinance No. 1556: National Health Surveillance System \\
\hline 1990 & & Law No 8080: Unified Health System (SUS) \\
\hline 1990 & & Law No 8078: National Policy for Consumer Relations \\
\hline 1985 & & First legislation about preservatives used in cosmetic products \\
\hline 1981 & & Creation of INCQS \\
\hline 1980 & & First specific legislation about cosmetic products \\
\hline 1978 & & $\begin{array}{l}\text { Ordinance No. 270: Creation of the Division of Cosmetics } \\
\text { (DICOP) }\end{array}$ \\
\hline 1976 & - & Decree No. 79056: Organization of the Ministry of Health \\
\hline 1976 & & Law No. 6360: Health Surveillance \\
\hline 1973 & & Creation of $A B C$ \\
\hline 1961 & & National Health Code \\
\hline 1957 & & National Service for Supervision of Medicine and Pharmacy \\
\hline 1953 & & Creation of Ministry of Health \\
\hline 1946 & & Decree No. 20397: Regulation of the Pharmaceutical Industry \\
\hline 1946 & & First reference about safety of cosmetics \\
\hline 1941 & & $\begin{array}{l}\text { Creation of Ministry of Education and Health and the National } \\
\text { Health Department }\end{array}$ \\
\hline 1930 & & Creation of Ministry of Education and Public Health \\
\hline 1930 & & Development of the Chemical-Pharmaceutical Industry \\
\hline 1923 & & $\begin{array}{l}\text { Decree No. 16300: Restructuring of the National Department of } \\
\text { Public Health }\end{array}$ \\
\hline 1920 & & Census indicated 13336 industries in the country \\
\hline 1920 & & Creation of the National Department of Public Health \\
\hline 1910 & & Second phase of the Sanitary Movement \\
\hline 1904 & - & First phase of the Sanitary Movement \\
\hline
\end{tabular}

FIGURE 1 - Overview of the regulatory milestones in the 20th century before ANVISA.

In Brazil, the first decade of the $20^{\text {th }}$ century was marked by the first phase of the Sanitary Movement, when Oswaldo Cruz was Chief Executive of Public Health for the urban sanitation of the Rio de Janeiro (FUNASA, 2004; 2014; Hamilton, Fonseca, 2003; Lima, Pinto, 2003; Stuart, 1914). At that time, the regulation of the Brazilian Health Services was defined (Brasil, 1904; Rozenfeld, 2000).

In 1910, the second phase of the Sanitary Movement was characterized by rural sanitation and the initiatives of the Oswaldo Cruz Institute with scientific expeditions to various parts of the country to learn about the health of the population. In this phase, the organization of a specific Ministry of Health was also under discussion in the National Congress (Hamilton, Fonseca, 2003; Lima, Pinto, 2003).

In addition, several health surveys were conducted early in the 20th century in Brazil, mainly in São Paulo, regarding the control of medicines, foods and shops
(Rozenfeld, 2000; Stuart, 1914), including those selling cosmetic products.

Despite these actions, due to the precarious health and diseases of the population, the focus of the legislation was mainly on hygiene and health issues.

In 1920, the Decree-Law No 3987 was published by the National Department of Public Health (DNSP), under the Ministry of Justice and Internal Affairs, replacing the General Directorate of Public Health, which was established in 1897 . With this decree, the DNSP became responsible for the actions on health surveillance, including urban and rural sanitation; child care services; the supervision of industrial and professional hygiene; the supervision of pharmaceuticals and other health-related products for sale; the supervision of hospitals; the supervision of health-related advertising; and the control of endemic and epidemic diseases (Brasil, 1920; Rozenfeld, 2000).

However, the actions of the DNSP were not successful due to the limitations of the country, with the 1920 Census indicating the presence of 13336 industries in Brazil. The food industry occupied first place, but the foreign chemical-pharmaceutical industry began to settle in the country (Souza, 1927; Rozenfeld, 2000).

Decree No16300 was published in 1923 and the actions of the DNSP were supplemented and restructured. Thus, the professional inspection of drugstores, pharmacies, laboratories and industries was regulated, as well as the licensing and inspection of pharmaceutical products, cosmetics and other healthrelated products (Brasil, 1923).

The focus on industrial hygiene issues was important because the absence of control in industrial establishments could also expose consumers to health risks. Thus, the industry, particularly the Pharmaceutical Industry, and its products began to be monitored. This control led to the first actions of punishment, as well as orientation of the industrial area.

In 1930, with the emergence of the new Brazilian state, characterized as a strong and centralized state, industrialization represented a form of development, with a significant growth of the Chemical-Pharmaceutical Industry (Rozenfeld, 2000), as also observed in other countries. This decade represented the beginning of the "Golden Age" of the Pharmaceutical Industry.

The industrial growth resulted from political and economic issues, but the Cosmetic Industry remained unregulated, without specific guidance about GMP and the development of safe and effective products.

During the same period, Decree No19402 created the Ministry of Education and Public Health (MESP), 
representing the control of public health linked to education (Brasil, 1930; FUNASA, 2004; 2014; Hochman, 2005), but the proposal of health centralization was still under discussion (Hamilton, Fonseca, 2003). All public health actions were concentrated in this new Ministry and the DNSP was incorporated into it (FUNASA, 2004; 2014). According to Hochman (2005), the creation of the MESP did not represent changes in public health because it only incorporated the DNSP and, at the end of the Provisional Government, it still had no defined objectives.

However, during the administration of MESP by Gustavo Capanema, significant reforms occurred, such as new directions and the restructuring of the public health administration. The Ministry was renamed Ministry of Education and Health (MES) and the DNSP was renamed National Department of Health (DNS). In addition, the Federal Police Health Stations were created, which were designed to inspect health actions, as well as health facilities. The National Health Conference (CNS) proposed the meeting of delegations from all states to discuss issues related to public health and the National Health Service was created, being responsible for fighting diseases and holding campaigns to prevent epidemics (Brasil, 1941b; Pandolfi, 1999; Hochman, 2005).

In 1941, during the $1^{\text {st }}$ National Health Conference in Rio de Janeiro (Brasil, 1941a), some representatives from Brazilian regions questioned the lack of a discussion about the creation of a specific Ministry of Health (Hamilton; Fonseca, 2003). Over the following years, the discussion about the creation of a separate Ministry of Health continued, mainly among physicians and health workers (Garret et al., 1995). It intensified with the end of World War II, as a result of "sanitary optimism" and with the advances in the development of vaccines and in the control of infectious diseases (Macnalty, 1952; Garret et al, 1995).

After four decades of the Sanitary Movement, the discussion about the creation of a Ministry centralized on health issues was still considered necessary. The reforms made did not meet all the needs of the Brazilian Health Surveillance, including those related to the Cosmetic Industries. Thus, Decree No 20397 was published to regulate the Pharmaceutical Industry. This decree regulates the marketing of pharmaceuticals and other health-related products, including cosmetics, which could then be marketed after submission to safety evaluation. The standardization of the industry supervision, licenses and the requirement of a responsible pharmacist in these establishments were also included in this document (Brasil, 1946).
The regulation of the Pharmaceutical Industry also provided a regulatory basis for the Cosmetic Industry and for the first time safety evaluation was required before marketing a product. However, no guidance was available about the studies. In addition, this regulation did not include any issues related to the efficacy of these products. Thus, the Cosmetic Industry had no guidance for the development of safe and effective products, but was forced to regulate them with safety studies.

In 1952, the second government of Getúlio Vargas determined changes in state structure and proposed a new portfolio for health. This resulted in discussions about the incorporation of Public Health into the Health Care Services of Social Security, creating the Ministry of Social Services (Hamilton, Fonseca, 2003).

In 1953, the political crisis in the government resulted in an emergency action with the project previously presented being approved by the Senate, and the on July 25, 1953, Law No 1920 created the Ministry of Health (MS) (Brasil, 1953; Hamilton; Fonseca, 2003).

All the organs and services of MES were transferred to the MS, including the National Medicine Inspection Service responsible for sanitary control of establishments and health-related products, including the Cosmetic Industry (Brasil, 1953). Four years later, the National Service for Supervision of Medicine and Pharmacy (SNFMF) was approved, a member agency of the DNS with the function of coordinating and supervising the practice of medicine and correlated activities (Brasil, 1957; Estefan, 1986; Rozenfeld, 2000).

The SNFMF was composed of professionals from the Chemical-Pharmaceutical Industry, Pharmacists, Teachers, Biologists and Physicians. This agency was responsible for the new substances or methods, including their chemical, pharmacological and therapeutic specifications; for establishing requirements about health issues linked to the industry; for the technical and scientific development of the industry; for issuing licenses to health establishment, including the Cosmetic Industries, and for the suspension of the license for a product marketed in disagreement with regulations (Brasil, 1957; Rozenfeld, 2000).

The creation of the SNFN represented a milestone in the history of Brazilian Health Regulation because it was structured with the involvement of many health professionals, disseminating multidisciplinary knowledge about standards and guidelines for the regulation of industries, including the Cosmetic Industry.

This involvement of professionals and competent organs represented the beginnings of supervision of the marketing of safe cosmetic products, since the SNFMF 
aimed to provide data about raw materials, including specifications, which could provide guidance about the use of safe and effective cosmetic ingredients. In this context, in 1961, Law No2312 was issued through Decree No49974-A, regarding the National Health Code (CNS), which established general rules for health protection. The National Health Code defined the State health requirements for each individual (Brasil, 1961).

The development of the CNS consolidated the trend in the country about the protection, promotion and restoration of health and regulated the sanitary control of the health establishments, including the Cosmetic Industries. Thus, the CNS represented a significant portion of the action of the Health Authorities regarding individual and collective health and included for the first time the standards and guidelines about industrial waste, representing an important action about environmental and health issues.

In 1976 , as a result of the discussions of the safety of health-related products, Law No 6360 was published, later regulated by Decree No 79094 of 1977 about Health Surveillance rules to which medicines, pharmaceutical, cosmetics and sanitizing products were submitted (Brasil, 1976, p. 1). This legislation provided the standards and guidelines for the licensing of the Cosmetic Industries, registration of cosmetic products, quality control, advertising, labeling, packaging, transportation of products, and information related to inspections, violations, penalties, and toxicity (Brasil, 1976).

The regulatory responsibilities of the cosmetic area, such as the issue of technical advice, licensing of establishments, inspection of facilities and application of punishments were centralized in the MS, which still had other responsibilities regarding public health (Brasil, 1976). .Also in 1976, the MS was restructured by Decree No 79056, with a redefinition of the organ and its competencies. It was established that the MS would be responsible for cosmetic norms and standards and the Health Surveillance Secretariat (SNVS) was established (Brasil, 1976).

Although not specifically concerning the cosmetic area, Law No 6360 was the first law containing important requirements and guidelines, which had not been previously described. The abolition of the use of toxic ingredients, an important requirement for the development of safe products, was also included. However, this was not enough to meet all needs of the cosmetic area.

The 70's were also marked by the founding of the Brazilian Association of Cosmetology (ABC), a non-profit association for the development of National Cosmetology (ABC, 2015). The creation of the ABC also contributed to the regulation of shortcomings and guidance for the cosmetics area.

Moreover, in 1978 the SNVS was divided into specific departments such as the Division of Cosmetics (DICOP) containing the following services: Technical Analysis Service, Cosmetic Dermatology Service, Registration Service, Technical Documentation Service, and Inspection and Control Service (Brasil, 1978).

Thus, the DICOP was responsible for organizing, controlling and monitoring norms and standards related to cosmetic products (Brasil, 1978). However, according to the first DICOP publication in 1980, the cosmetic regulation was published together with the sanitation regulation (Brasil, 1980). This first publication concerned the substances that could be used in cosmetic products (Brasil, 1980). During the action of the DICOP, other ordinances were published, but none was directly related tothe safety and efficacy of these products, or Good Manufacturing Practices. However, Ordinance REC-2 in 1981 presented criteria about the protection against tanning products (Brasil, 1981), Ordinances PRT-1 and PRT-2 in 1982 and 1983, respectively, published information about lead acetate in cosmetic products (Brasil, 1982; 1983), and in 1985 for the first time an ordinance was published about preservatives that could be used in cosmetic products (Brasil, 1985).

Thus, the creation of the MS, so necessary for public health issues, resulted in the process of regulation of the Cosmetics Industry in Brazil, with a positive impact on the safety of the products marketed in this country. However, this process was not sufficient to regulate all relevant issues of the cosmetic area despite the creation of the DICOP.

The National Institute of Quality Control in Health (INCQS) was created in the early 80's, with expertise in the areas of teaching, research and technology, quality control of raw materials, products, environments and services submitted to the action of Health Surveillance (Rozenfeld, 2000; FUNASA, 2004; 2014; INCQS, 2014). The creation of the INCQS was important regarding actions of health surveillance for product control by laboratory analysis, using quality control methodologies.

Law No 8080 was then published in 1990, regulating the actions of public or private health services in the national territory, including the promotion, protection and restoration of health. In addition, the Unified Health System (SUS) became responsible for all of these actions (Brasil, 1990a; Rozenfeld, 2000). The Health Surveillance actions were also under the responsibility of the SUS (Brasil, 1990b). 
Also during the 1990's, the Technical Regulation for the Inspection of Food Industries was approved by Ordinance No1428 of 1993. This Regulation approved the guidelines for Good Manufacturing Practices, and the implementation of quality standards for services and products in the food area (Brasil, 1993).

The sanitary regulation of the food area predicted what would happen later in the drug and cosmetic areas because it regulated the manufacturing processes according to quality standards, providing guideline for sanitary inspections and mainly for the safety of their products and their impact on consumer health.

Ordinance No 1556, based on Law No 8080, was published the following year, establishing the National Health Surveillance System (SNVS) coordinated by SUS, clarifying the responsibilities of the Federal Government, States, Federal District and cities regarding Health Surveillance and Epidemiological Surveillance (Brasil, 1994; Rozenfeld, 2000; Corrêa, 2003; Rediguieri, Rediguieri, Vieira, 2013).

Complementing the changes in Health Surveillance in the 90's, in 1995, Ordinance No 17 was published, establishing the National Program for Inspection of Pharmaceutical and Pharmochemical Industries (PNIFF), and defining the conditions for the implementation of Good Manufacturing Practices for the Pharmaceutical and Pharmocheminal Industries, as well as importers and exporters (Eduardo, Miranda, 1998; Rozenfeld, 2000; Corrêa, 2003; Rediguieri, Rediguieri, Vieira, 2013).

Ordinance No 16 was published next, containing recommendations for the Pharmaceutical Industry for the implementation of Good Manufacturing Practices based on the "Guide to Good Manufacturing Practices" (Brasil, 1995; Eduardo, Miranda, 1998; Rozenfeld, 2000; Corrêa, 2003; Rediguieri, Rediguieri, Vieira, 2013).

Also in 1995, the Advisory Technical Committee on Cosmetics (CTAC) was established to provide advice on cosmetic products issues (ANVISA, 2004). The creation of CTAC was important by assisting the cosmetic area about issues mainly related to the safety of products. In addition, the Brazilian Association of Cosmetic, Toiletry and Perfumery Industries (ABIHPEC) was created in order to represent the Cosmetic Industry regarding its actionsandt progress in the country (ABIHPEC, 2015).

In line with the developments related to Good Manufacturing Practice, Ordinance No 327 of 1997 was published for the regulation of Good Manufacturing Practices in the Sanitation Industry (Brasil, 1997a).

Then, in 1997, Ordinance No348 was published the for the regulation of Good Manufacturing Practices in the Cosmetic Industries due to the need to update health control in the area of personal care products, cosmetics and perfumes. In addition, an Inspection Guide was available about sanitary inspections (Brasil, 1997b).

Ordinance No 348 was the first publication about Good Manufacturing Practices for the cosmetic area and also represented the last publication related to this area before the creation of the ANVISA.

The changes in the food, medicine and sanitation areas in the 90's resulted in changes in the cosmetics area and also had a positive impact on the sanitary regulation of this area, in terms of safe cosmetic products, although no guidelines were provided about the necessary studies for the development of safe and effective products.

In short, important indirect regulatory milestones and a specific regulation marked the cosmetic area during the 20th century. However, despite the regulatory developments, mainly after the creation of MS, some problems still persisted, related to RD\&I of safe and especially effective products. In addition, some requirements about safety were published, although without guidance about studies and methodologies.

Furthermore, as evaluated by Bellan et al. (2012), in a study on pharmaceutical legislation, it is important the participation of society, governmental agencies and industry on issues related to the regulation.

Finally, this study represents an important contribution to the cosmetic area because it provides data needed to understand the challenges faced by the Cosmetic Industry before ANVISA and shows the importance of a regulatory basis as technical support in the RD\&I of cosmetic products, resulting in safe, effective and innovative products.

\section{CONCLUSION}

In this study, it was possible to conclude that the $20^{\text {th }}$ century was marked by actions of the federal government in sanitary surveillance in Brazil, highlighting the sanitary movements, the creation of the Ministry of Health and the institution of the National Health Surveillance System.

In this context, the cosmetic area also had regulatorymilestones, although it could also be concluded that the actions preceding the creation of ANVISA were insufficient, so that the area remained without requirements and guidelines about the development of safe products. The need for safe products was required, but only in 1946 and no other information about preclinical and clinical studies was published, which represented a challenge for the Cosmetic Industry at that time. In addition, no legislation or guidance about the efficacy of cosmetic products was detected, which also represented a challenge for the Cosmetic Industry. 
Moreover, if not considered responsible, the industry could use claims without the need to support them with preclinical and clinical studies.

If on the one hand the events resulted in the creation of ANVISA, on the other the challenges faced by the Cosmetic Industry at that time could have a negatively impact on the health of the consumers of these products. Thus, the creation of ANVISA was essential to meet the challenges of the cosmetic area related to the safety and efficacy of its products.

\section{ACKNOWLEDGEMENTS}

CNPq - National Counsel of Technological and Scientific Development.

\section{REFERENCES}

ASSOCIAÇÃO BRASILEIRA DE COSMETOLOGIA. ABC. $A A B C$. 2015. Available at: $<$ http://www.abc-cosmetologia. org.br/a-abc/>. Accessed on: 20 Feb. 2015.

ASSOCIAÇÃO BRASILEIRA DA INDÚSTRIA DE HIGIENE PESSOAL, PERFUMARIA E COSMÉTICOS. ABIHPEC. Histórico da Entidade. São Paulo, 2015. Available at: $<$ http://www.abihpec.org.br/institucional/abihpec/>. Accessed on: 20 Feb. 2015.

\section{ASSOCIAÇÃO BRASILEIRA DA INDÚSTRIA DE HIGIENE} PESSOAL, PERFUMARIA E COSMÉTICOS. ABIHPEC. Panorama do Setor. São Paulo, 2013. Available at: $<$ http:// www.abihpec.org.br/wp-content/uploads/2013/04/ Panorama-do-setor-PORT-05Abr2013.pdf $>$. Accessed on: 20 Feb. 2015.

AGÊNCIA NACIONAL DE VIGILÂNCIA SANITÁRIA. ANVISA. Pareceres Técnicos. Brasília, DF, 2004. Available at: <http://portal.anvisa.gov.br/wps/content/Anvisa+Portal/ Anvisa/Inicio/Cosmeticos/Assuntos+de+Interesse/ Camara+Tecnica>. Accessed on: 24 nov. 2014.

BELLAN, N.; PINTO, T.J.A.; KANEKO, T.M.; MORETTO, L.D.; SANTOS JÚNIOR, N. Critical analysis of the regulations regarding the disposal of medication waste. Braz. J. Pharm. Sci., v.48, n.3, p.507-518, 2012.

BRASIL. Decreto ${ }^{\circ} 16300$, de 31 de dezembro de 1923. Aprova o Regulamento do Departamento Nacional de Saúde Pública, Rio de Janeiro, RJ, 1923. Available at: <http:// conselho.saude.gov.br/biblioteca/Relatorios/relatorio_1. pdf>. Accessed on: 27 nov. 2014.
BRASIL. Decreto ${ }^{\circ} 19402$, de 14 de novembro de 1930. Cria uma Secretaria de Estado com a denominação de Ministério dos Negócios da Educação e Saúde Pública, Rio de Janeiro, RJ, 1930. Available at: <http://www2.camara.leg.br/legin/ fed/decret/1930-1939/decreto-19402-14-novembro-1930515729-publicacaooriginal-1-pe.html>. Accessed on: 28 Nov. 2014

BRASIL. Decreto no 20397, de 14 de janeiro de 1946. Aprova o Regulamento da Indústria Farmacêutica no país, Rio de Janeiro, RJ, 1946. Available at: <http://www2.camara.leg. br/legin/fed/decret/1940-1949/decreto-20397-14-janeiro1946-327522-publicacaooriginal-1-pe.html $>$.Accessed on: 28 Nov. 2014.

BRASIL. Decreto n ${ }^{\circ} 41904$, de 29 de julho de 1957. Aprova o Regimento de Serviço Nacional de Fiscalização da Medicina e Farmácia, do Ministério da Saúde, Rio de Janeiro, RJ, 1957. Available at: <http://www2.camara.leg. br/legin/fed/decret/1950-1959/decreto-41904-29-julho1957-380811-publicacaooriginal-1-pe.html >. Accessed on: 28 nov. 2014

BRASIL. Decreto no 49974-A, de 21 de janeiro de 1961. Regulamenta, sob denominação de Código Nacional de Saúde, a Lei No 2.312, de 3 de Setembro de 1954, de normas gerais sobre a defesa e proteção da saúde. Brasília, DF, 1961. Available at: <http://www2.camara.leg.br/legin/ fed/decret/1960-1969/decreto-49974-a-21-janeiro-1961333333-publicacaooriginal-1-pe.html>. Accessed on: 28 nov. 2014.

BRASIL. Decreto $n^{\circ} 5156$, de 08 de março de 1904. Dá novo regulamento aos Serviços Sanitários a cargo da União, Rio de Janeiro, RJ, 1904. Available at: <http://www2.camara. leg.br/legin/fed/decret/1900-1909/decreto-5156-8-marco1904-517631-publicacaooriginal-1-pe.html >. Accessed on: 28 nov. 2014.

BRASIL. Decreto $n^{\circ}$ 6788, de 30 de janeiro de 1941. Convoca a $1^{\text {a }}$ Conferência Nacional de Educação e a $1^{\text {a }}$ Conferência Nacional de Saúde e dá outras providências, Rio de Janeiro, RJ, 1941a. Available at: <http://www2.camara.leg.br/legin/ fed/decret/1940-1949/decreto-6788-30-janeiro-1941331348-publicacaooriginal-1-pe.html>. Accessed on: 28 nov. 2014. 
BRASIL. Decreto n ${ }^{\circ} 79056$, de 30 de dezembro de 1976. Dispõe sobre a organização do Ministério da Saúde e dá outras providências, Brasília, DF, 1976. Available at: <http:// www2.camara.leg.br/legin/fed/decret/1970-1979/decreto79056-30-dezembro-1976-428077-retificacao-1-pe.html>. Accessed on: 28 nov. 2014.

BRASIL. Decreto-Lei no 3171 , de 02 de abril de 1941. Reorganiza o Departamento Nacional de Saúde, do Ministério da Educação e Saúde, e dá outras providências, Rio de Janeiro, RJ, 1941b. Available at: <http://www2. camara.leg.br/legin/fed/declei/1940-1949/decreto-lei3171-2-abril-1941-413188-publicacaooriginal-1-pe.html>. Accessed on: 28 nov. 2014.

BRASIL. Lei no 1920 , de 25 de julho de 1953. Cria o Ministério da Saúde e dá outras providências, Rio de Janeiro, RJ, 1953. Available at: <http://www.planalto.gov.br/ccivil_03/ leis/1950-1969/L1920.htm>. Accessed on: 28 nov. 2014.

BRASIL. Lei n ${ }^{\circ} 3820$, de 11 de novembro de 1960 . Cria o Conselho Federal e os Conselhos Regionais de Farmácia, e dá outras providências. Brasília, DF, 1960. Available at: $<$ http://www.planalto.gov.br/ccivil_03/leis/13820.htm>. Accessed on: 27 nov. 2014.

BRASIL. Lei no 3987, de 02 de janeiro de 1920. Reorganiza os Serviços de Saúde Pública, Rio de Janeiro, RJ, 1920. Available at: <http://www2.camara.leg.br/legin/ fed/lei/1920-1929/lei-3987-2-janeiro-1920-570495publicacaooriginal-93627-pl.html>. Accessed on: 28 nov. 2014.

BRASIL. Lei n 6360, de 23 de setembro de 1976. Dispõe sobre a Vigilância Sanitária a quem ficam sujeitos os Medicamentos, as Drogas, os Insumos Farmacêuticos e Correlatos, Cosméticos, Saneantes e Outros Produtos, e dá outras Providências. Brasília, DF, 1976. Available at: $<$ http://www.planalto.gov.br/ccivil_03/leis/16360.htm>. Accessed on: 28 nov. 2014

BRASIL. Lei $n^{\circ}$ 6437, de 20 de agosto de 1977. Configura infrações à legislação sanitária federal, estabelece as sanções respectivas, e dá outras providências, Brasília, DF, 1977. Available at: <http://www.planalto.gov.br/ccivil_03/ leis/16437.htm>. Accessed on: 28 nov. 2014.

BRASIL. Lei $n^{\circ}$ 8078, de 11 de setembro de 1990. Dispõe sobre a proteção do consumidor e dá outras providências, Brasília, DF, 1990a. Available at: <http://www.planalto.gov. br/ccivil_03/leis/18078.htm>. Accessed on: 28 nov. 2014.
BRASIL. Lei n ${ }^{\circ}$ 8080, de 19 de setembro de 1990. Dispõe sobre as condições para a promoção, proteção e recuperação da saúde, a organização e o funcionamento dos serviços correspondentes e dá outras providências, Brasília, DF, 1990b. Available at: < http://www.planalto.gov.br/ccivil_03/ leis/18080.htm>. Accessed on: 28 nov. 2014.

BRASIL. Lei no 9782, de 26 de janeiro de 1999. Define o Sistema Nacional de Vigilância Sanitária, cria a Agência Nacional de Vigilância Sanitária, e dá outras providências, Brasília, DF, 1999. Available at: <http://www.planalto.gov. br/ccivil_03/leis/19782.htm>. Accessed on: 01 dez. 2014.

BRASIL. Ministério da Saúde. Portaria no 1428 , de 26 de novembro de 1993, Brasília, DF, 1993. Available at: <http://www.mds.gov.br/acesso-a-informacao/legislacao/ segurancaalimentar/portarias/1993/Portaria,P20Anvisa,P 20no,P201.428.93.pdf.pagespeed.ce.KavnQGBZHh.pdf>. Accessed on: 28 nov. 2014.

BRASIL. Ministério da Saúde. Portaria n ${ }^{\circ} 1565$, de 26 de agosto de 1994, Brasília, DF, 1994. Available at: <http://bvsms.saude.gov.br/bvs/saudelegis/gm/1994/ prt1565_26_08_1994.html>. Accessed on: 28 nov. 2014.

BRASIL. Ministério da Saúde. Portaria nº 16, de 6 de março de 1995, Brasília, DF, 1995. Available at: <http://www.natal. rn.gov.br/sms/biblioteca/legislacao/legis_a_normativos/ legis_vigilancia/legis_produtos/portaria_19950306_ ms_016.doc>.Accessed on: 28 nov. 2014.

BRASIL. Ministério da Saúde. Portaria no 270-BSB de 19 de junho de 1978. Brasília, DF, 1978. Available at: < https:// www.incqs.fiocruz.br/images/stories/incqs/legislacao/ portaria-270_19-06-1978.pdf>. Accessed on: 18 aug. 2015.

BRASIL. Ministério da Saúde. Portaria n ${ }^{0}$ 327, de 30 de julho de 1997. Brasília, DF, 1997a. Available at: <http://www. aeap.org.br/doc/portaria_327_de_30_de_julho_de_1997. pdf $>$. Accessed on: 28 nov. 2014.

BRASIL. Ministério da Saúde. Portaria no 348, de 18 de agosto de 1997. Brasília, DF, 1997b. Available at: <http://bvsms.saude.gov.br/bvs/saudelegis/svs1/1997/ prt0348_18_08_1997_1.html>.Accessed on: 28 nov. 2014.

BRASIL. Ministério da Saúde. Portaria PRT-1 de 11 de novembro de 1982. Brasília, DF, 1982. Available at: <http:// portal2.saude.gov.br/saudelegis/leg_norma_pesq_consulta. cfm>. Accessed on: 18 ago. 2015. 
BRASIL. Ministério da Saúde. Portaria PRT-1 de 25 de fevereiro de 1985. Brasília, DF, 1985. Available at: <http://portal2. saude.gov.br/saudelegis/leg_norma_pesq_consulta.cfm $>$. Accessed on: 18 ago. 2015.

BRASIL. Ministério da Saúde. Portaria PRT-1 de 27 de agosto de 1980. Brasília, DF, 1980. Available at: <http://portal2. saude.gov.br/saudelegis/leg_norma_pesq_consulta.cfm $>$. Accessed on: 18 ago. 2015.

BRASIL. Ministério da Saúde. Portaria PRT-2 de 31 de outubro de 1983. Brasília, DF, 1983. Available at: <http://portal2. saude.gov.br/saudelegis/leg_norma_pesq_consulta.cfm $>$. Accessed on: 18 ago. 2015.

BRASIL. Ministério da Saúde. Portaria REC-2 de 24 de agosto de 1981. Brasília, DF, 1981. Available at: <http://portal2. saude.gov.br/saudelegis/leg_norma_pesq_consulta.cfm $>$. Accessed on: 18 ago. 2015.

CORRÊA, J.C.V. Qualidade dos medicamentos comercializados no Brasil segundo dados do Instituto Nacional de Controle de Qualidade em Saúde e do Instituto Adolfo Lutz. 2003. 152 f. Dissertação (Mestrado em Ciências) - Faculdade de Ciências Farmacêuticas, Universidade de São Paulo, São Paulo, 2003.

EDUARDO, M.B.P.; MIRANDA, I.C.S. Vigilância sanitária. São Paulo: Fundação Peirópolis, 1998. 460 p.

ESTEFAN, I.J.S. O Ensino de Farmácia. Cad. Saúde Pública, v.2, n.4, p.511-532, 1986.

FELDSTEIN, P.J.; MELNICK, G. Congressional voting behavior on hospital legislation: an exploratory study. $J$. Health Polit. Polic., v.8, n.4, p.686-701, 1984.

FUNDAÇÃO NACIONAL DE SAÚDE. FUNASA. 100 anos de Saúde Pública: a visão da Funasa. 2004. Available at: <http://www.funasa.gov.br/site/wp-content/files_mf/ livro_100-anos.pdf>. Accessed on: 03 Sep. 2014.

FUNDAÇÃO NACIONAL DE SAÚDE. FUNASA. Cronologia Histórica da Saúde Pública. 2014. Available at: <http:// www.funasa.gov.br/site/museu-da-funasa/cronologiahistorica-da-saude-publica/>. Accessed on: 18 Sep. 2014.

GARRET, L.; SIESSERE, S.; APPENZELLER, M.; BLACK, M.D. A próxima peste: novas doenças num mundo em desequilíbrio. Rio de Janeiro: Nova Fronteira, 1995. 710 p.
GIL, A.L. Métodos e técnicas de pesquisa social. 6. ed. São Paulo: Atlas, 2008. 200 p.

HAMILTON, W.; FONSECA, C. Política, atores e interesses no processo de mudança institucional: a criação do Ministério da Saúde em 1953. Hist. Cienc. Saude-Manguinhos, v.10, n.3, p.791-825, 2003.

HERIOT, K.; LANG, T.; THOMPSON, N. Evaluating the Impact of Federal Legislation on Small Businesses: An Exploratory Study of the New Minimum Wage Rate and the Health Insurance Tax. Small Bus. Inst. J., v.6, p.63-90, 2010.

HOCHMAN, G. Political changes and public health reform in BRASIL. The first Vargas government (1930-1945). Dynamis, v.25, p.199-226, 2005.

INSTITUTO NACIONAL DE CONTROLE DE QUALIDADE EM SAÚDE. INCQS. Apresentação. 2014. Available at: $<$ http://www.incqs.fiocruz.br/index.php?option=com_con tent $\&$ view $=$ article $\& i d=61 \&$ Itemid $=57>$. Accessed on: 18 Sep. 2014.

LIMA, A.L.G.S.; PINTO, M.M.S. Fontes para a história dos 50 anos do Ministério da Saúde. Hist. Cienc. SaudeManguinhos, v.10, n.3, p.1037-1051, 2003.

LORENZO, V.D. Legislative chaos: an exploratory study. Yale L. \& Pol'y Rev., v.12, n.2, p.425-485, 1994.

MACNALTY, A.S. International sanitary regulations. Nature, v.170, p.1107-1108, 1952.

PANDOLFI, D. Repensando o Estado Novo. 1 ed. Rio de Janeiro: Fundação Getúlio Vargas, 1999. 345p.

RAUPP, F.M.; BEUREN, I.M. Metodologia da pesquisa aplicável às ciências sociais. In: BEUREN, I.M.(Ed.) Como elaborar trabalhos monográficos em contabilidade: teoria e prática. São Paulo: Atlas, 2003, p.76-97.

REDIGUIERI Camila, F.; REDIGUIERI Carolina, F.; VIEIRA, F.P. A Regulação de medicamentos no Brasil. 1 ed. Rio de Janeiro: Artmed, 2013. 672p.

ROZENFELD, S. Fundamentos da vigilância sanitária. 1 ed. Rio de Janeiro: Fiocruz, 2000. 304 p.

SÁ-SILVA, J.R.; ALMEIDA, C.D.; GUINDANI, J.F. Documentary research: theoretica land methodological clues. Rev. Bras. Hist. Cienc. Soc., n.1, p.1-15, 2009. 
SETO, Y.; HOSOI, K.; TAKAGI, H.; NAKAMURA, K.; KOJIMA, H.; YAMADA, S.; ONOUE, S. Exploratory and regulatory assessments on photosafety of new drug entities. Curr. Drug Saf., v.7, n.2, p.140-148, 2012.

SOUZA, I. E. Recenseamento do Brasil. Rio de Janeiro: Typ Estatística, 1927. 526 p.
STUART, E. Sanitation in BRASIL. Am. J. Public Health, v.4, n.12, p.1159-1172, 1914.

Received for publication on $30^{\text {th }}$ September 2015 Accepted for publication on $12^{\text {th }}$ April 2016 